Dear Author,

Please, note that changes made to the HTML content will be added to the article before publication, but are not reflected in this PDF.

Note also that this file should not be used for submitting corrections. 


\title{
Towards understanding and resolving the conflict related to the Eastern Imperial Eagle (Aquila heliaca) conservation with participatory management planning
}

\author{
${ }_{4}$ Q1 Eszter Kovács ${ }^{\mathrm{a}, \mathrm{b}, *}$, Veronika Fabók ${ }^{\mathrm{a}, \mathrm{b}}$, Ágnes Kalóczkai ${ }^{\mathrm{a}, \mathrm{b}, \mathrm{c}}$, Hans Peter Hansen ${ }^{\mathrm{d}}$ \\ a Szent István University, Institute of Nature Conservation and Landscape Management, Páter Károly u. 1., Gödöllő H-2100, Hungary \\ ${ }^{\mathrm{b}}$ Environmental Social Science Research Group (ESSRG), Rómer Flóris u. 38., Budapest H-1024, Hungary \\ ' MTA Centre for Ecological Research, Alkotmány u. 2-4., Vácrátót H-2163, Hungary \\ d Swedish University of Agriculture (SLU), Unit of Environmental Communication, Department of Urban and Rural Development, Ulls väg 28,75007 \\ Uppsala, Sweden
}

* Corresponding author at: Szent István University, Institute of Nature Conservation and Landscape Management, Páter K. u. 1., Gödöllő H-2100, Hungary.

E-mail address: kovacs.eszter@mkk.szie.hu (E. Kovács). stakeholder perceptions and the main drivers of conflict situations have in recent decades become the focus of many research projects on conservation conflicts, especially those regarding predator species (Zimmermann et al., 2005; Václavíková et al., 2011; Arthur et al., 2013; O’Rourke, 2014).

Stakeholder participation, especially with regard to participatory planning and management, is gaining importance in nature conservation. It is often highlighted that participation can serve as a good instrument for mitigating or resolving conservation conflicts (Messmer, 2000; Treves et al., 2006, 2009; Reed, 2008; Jones-Walters and Çil, 2011). Stakeholder involvement can help foster communication and build trust between conflicting parties, increase information and knowledge exchange, thus enhancing mutual learning, mobilising new ideas and improving the legitimacy of proposed management options (Bulkeley and Mol, 2003; Reed, 2008; Jones-Walters and Çil, 2011; Young et al., 2013). Conversely, participatory processes have limitations as well. As stated by Arnstein (1969) in his prominent paper, participation is often used without being defined, without clarification of its premises and formulation of the expected outcomes. Participatory processes usually require substantial financial resources and time from the involved parties. Power might be distributed unequally between participants during the process leading to unsatisfactory outcomes. Additionally, failures in the design and implementation of participatory processes often generate false expectations, mistrust and disillusionment, therefore even generate new or deepen existing conflicts (Bulkeley and Mol, 2003; Reed, 2008; Booth and Halseth, 2011; Díez et al., 2015). 
In conservation management, stakeholders are defined as those individuals, groups or organisations that can affect or are affected by a conservation related decision or action (Reed et al., 2009) or have a special interest in the management or use of certain ecosystems and/or their services (TEEB, 2010). It has been emphasised by a number of scholars that understanding the interests and views of stakeholders is important for the successful implementation of conservation objectives (Bagnoli et al., 2008; Rauschmayer et al., 2009; Jones-Walters and Çil, 2011). However, the use of the stakeholder concept together with participation has also been criticised for reinforcing the strategic dimension of participation at the expense of a collective responsibility (such as of nature conservation) based on mutual respect and a more deliberative approach (Hansen et al., in press). The stakeholder concept was popularised within business administration in the early 1980 s by Freeman (1984) without any sort of democratic intent. Therefore, some fundamental ambiguities emerge when labelling the participants in participatory processes 'stakeholders' or 'users' instead of 'citizens', 'residents' or 'community members'. If stakeholders are involved in participatory processes then the main focus is on their interests, while in cases of public involvement, opinions, preferences and values of citizens about a "common good" is highlighted (Pellizzoni, 2003). Nevertheless, we will argue that a stakeholder participation process, especially related to a conservation conflict can address not only interests, but common values as well. In addition, some conflicts are so rooted and reproduced by particular strategic predetermined interests that they need to be dealt with separately before any other participatory approaches are possible.

There are an increasing number of cases from Central and Eastern European (CEE) countries that present conservation conflicts or conservation related participation processes. Young et al. (2007) discuss potential conservation conflicts in CEE countries after accession to the European Union (EU), and propose participatory methods which can be used for future conflict management. Some existing CEE studies on conservation conflicts concentrate on different stakeholder perceptions and the drivers of conflicts in relation to the designation or management of protected areas (Grujčič et al., 2008; Blicharska and Angelstam, 2010; Anthony and Szabo, 2011; Václavíková et al., 2011; Niedziałkowski et al., 2014; Kovács et al., 2015) or on protected species (Kloskowski, 2011; Václavíková et al., 2011). Other studies discuss the result of participatory processes in nature conservation (Lawrence, 2008; Švajda, 2008; Malatinszky et al., 2013; Cent et al., 2014) or the need for involvement of local communities (Anthony and Moldovan, 2008). However, successful cases where stakeholder participation has been used to address or even mitigate conservation conflicts remain underreported from this particular region.

This paper attempts to fill this gap by describing how and to what extent a participatory management planning process could contribute to assessing and resolving a conflict in relation to the conservation of the Eastern Imperial Eagle (Aquila heliaca) in the Jászság Special Protection Area of European importance (SPA). Illegal poisoning of eagles seriously affecting the population had been present before the participatory process started thus indicating conflicts between different land user groups (MME, 2010). However, it is very difficult to trace down the poisoning incidents and to identify who was responsible. It is also uncertain if the eagles were the main target of this activity. Therefore, we did not focus on the poisoning, but used it to illustrate that a conflict exists. In this paper, we concentrate on the conflict between three primary stakeholder groups: farmers, game managers and nature conservationists. Initially we used a standardised stakeholder approach in the planning process as described in the stakeholder participation literature. However, as we will show, the later part of the process transcended the more strategic dimensions of the conflict and offered new insight to the discussion of stakeholder participation as well.

\section{Material and methods}

\subsection{Eastern Imperial Eagle (A. heliaca)}

The Eastern Imperial Eagle (A. heliaca) is a globally threatened species of the Eurasian forest steppe zone, with a world population of only a few thousand breeding pairs (Horváth et al., 2009). It is classified as 'vulnerable' on the IUCN Red list of Threatened Species (BirdLife International, 2013), listed in Annex I of the European Union's (EU) Birds Directive, and strictly protected in Hungary. Hungary hosts the largest population of this species in the EU, with 155-165 breeding pairs in 2012 (Horváth et al., 2012). In the early 1980 s, the population reached its lowest, with approximately 20 breeding pairs, but since then has continually increased, mostly due to concentrated monitoring and conservation efforts (Kovács et al., 2008; Horváth et al., 2009). The breeding area has expanded towards lowland agricultural areas, while habitats in mountainous areas have decreased (Horváth et al., 2014). The Eastern Imperial Eagle nests in patches of old forest or uses solitary trees or groups of trees for nesting, and research indicates that it is highly sensitive to disturbance (Kovács et al., 2005). It forages in grasslands and arable lands in a radius of a few kilometres around its nesting site (Horváth et al., 2009). The bird mainly preys on common hamster (Cricetus cricetus), European hare (Lepus europaeus), common pheasant (Phasianus colchicus) and souslik (Spermophilus citellus) (Kovács et al., 2005). Horváth et al. (2010) show that in recent years, there have been dramatic changes in the composition of the Imperial Eagle's diet: the souslik has almost disappeared from the diet, the ratio of hamsters being preyed on has decreased, while the ratio of hare has increased.

\subsection{The Jászság SPA (Special Protection Area)}

The Jászság SPA is situated in central Hungary, in the northern periphery of the Great Hungarian Plain and is part of a larger historical, ethnographical and geographical region of Hungary, called Jászság (see Fig. 1). The area belongs to the EU's Natura 2000 network of protected areas, due to the presence of the Eastern Imperial Eagle and other protected bird species (e.g. Falco cherrug, F. vespertinus). The natural vegetation of this area comprises salty grasslands, floodplain vegetation and small patches of hardwood forest (MME, 2010). The Jászság SPA constitutes one of the most important habitats for the Imperial Eagle within Hungary, with its 10-12 breeding pairs and 25-50 wintering individuals. Although its population has also increased in this area in recent years, it is threatened because of illegal poisoning, the possible disturbance of its nesting places, and the loss of habitat of its key prey species (MME, 2010, 2013). Between 2003 and 2009, 12 eagles were poisoned in this area, which is about third of the total reported poisoning cases in Hungary in this period (MME, 2010).

Nowadays, arable land is dominant in the SPA with some grassland and a few patches of small forest. The exact number of farmers is known only for the larger administrative region (less than 100 economic entities and over 7000 small farmers) (KSH, 2012). Most intensively cultivate arable land and some use grassland for mowing or grazing. There are only a few forest users in the area, cultivating small patches of forest.

Game management is significant in the SPA, with four hunting organisations operating in the region, specialising mostly in small game species including European hare (L. europaeus) and common pheasant (P. colchicus). Roe deer (Capreolus capreolus) is also hunted 


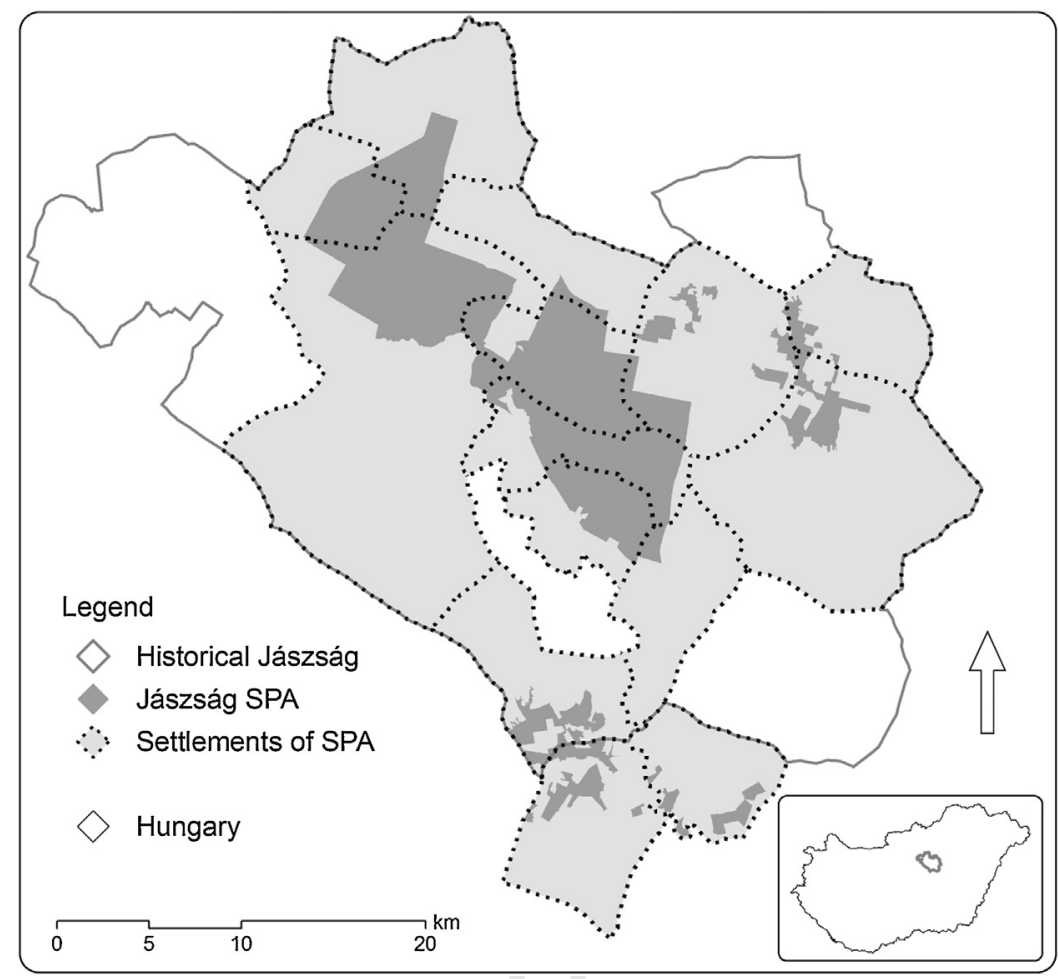

Fig. 1. Map of the study area.

here. The hunting organisations are responsible for the efficient game management and predator control in their operational area.

Due to the SPA's conservation status, the area is subject to nature conservation activities. The Hortobágy National Park Directorate (HNPD) is the main state conservation body operating at the site. It is responsible for the coordination of conservation activities, mainly supervising and monitoring protected areas and species of national and European importance. The MME's (Birdlife Hungary) local group is the most important nature conservation civil organisation present, focusing on the conservation of protected bird species and coordinating monitoring and other conservation activities. The MME and the HNPD cooperate closely; also in conservation activities related to the Imperial Eagle.

\subsection{Management planning process}

The preparation of management plans for Natura 2000 sites is not obligatory in Hungary and the conservation measures listed in the plan are voluntary as well (except for those taken from a specific regulation). The plan needs to be developed in consultation with local stakeholders, but methods for consultation and the level of participation are not specified in the legislation on Natura 2000 sites (Governmental degree No. 275/2004).

Within a LIFE $+{ }^{1}$ project on the conservation of Imperial Eagle in Hungary, a participatory management planning process was initiated by the MME in the Jászság SPA in order to secure the most important habitat for this bird of prey in Hungary. The management team comprised a planning team with conservation experts and a

\footnotetext{
${ }^{1}$ LIFE is the financial instrument of the European Union co-financing environmental, nature conservation and climate action projects. It has been operating since 1992 in 7-year phases adjusted to the EU's budget planning periods (http1). The phase between 2007 and 2013 was called LIFE+. The Nature and Biodiversity part of LIFE+ assisted in the implementation of the nature and biodiversity policy and regulation of EU, especially the Birds and Habitats Directives and the management objectives of the related Natura 2000 network (EC regulation No 614/2007).
}

facilitator team, with experts experienced in conservation-related participatory processes. The Hungarian authors of this paper were members of the facilitator team, responsible for the participatory process. The tasks included identifying the most important stakeholder groups in the area, compiling a stakeholder analysis for the planning team based on interviews with local stakeholder groups, and organising, facilitating and documenting consultation forums.

The entire planning process covered the period from September 2012 to October 2013, when the management plan was sent to the Ministry of Rural Affairs (currently Ministry of Agriculture) for approval. The management plan was approved in 2015.

\subsection{Methods}

\subsubsection{Methods for data gathering}

At the beginning of the participatory process, a desk study was conducted in order to gather information on the environmental, social and historical context of possible conservation conflicts in the SPA. It was followed by semi-structured interviews (Patton, 2002) with representatives of the most significant local stakeholder groups, to reveal the diversity of perceptions on nature conservation, the Imperial Eagle and conflicts between different stakeholder groups in the area (see the main themes of the interviews in Appendix A). The interviewees were selected through purposeful sampling and the 'snowball' method (Patton, 2002). Our sample consisted of local stakeholder groups that had had a significant impact on the status of habitats and species in the SPA. The local ranger of the national park directorate was our key informant, and helped us to compile an initial list of stakeholders. In addition, we used other sources of information (including the internet) to find contact details for other stakeholder groups and asked our interviewees to provide additional contacts. Altogether, 21 interviews with 20 interviewees were carried out between September-December 2012 , some were combined with a transect walk. The duration of each interview was $40-90 \mathrm{~min}$, with an average of an hour. They were conducted in pairs, with one researcher asking questions, the

Please cite this article in press as: Kovács, E., et al., Towards understanding and resolving the conflict related to the Eastern Imperial Eagle (Aquila heliaca) conservation with participatory management planning. Land Use Policy (2016), http://dx.doi.org/10.1016/j.landusepol.2016.02.011 
other taking notes. Recordings were not made due to the sensitivity of some of the issues, in order to increase the trust and openness toward the interviewers, and because it was specifically requested by some interviewees groups as part of the participatory planning process; the first one for a wider group of local stakeholders and the second for farmers and game managers only. The main aim of these forums was to collaboratively discuss the content of the management plan with the stakeholder groups and to reach consensus on the different nature conservation measures (see the Agenda of the forums in Appendix B). The two forums were held in a local hunting centre and were facilitated by an experienced facilitator of the team, responsible for the participatory process. They were recorded and literally transcribed.

Follow-up semi-structured individual and group interviews were also conducted with game managers and farmers who had been active during the stakeholder consultation, and with all conservation experts in the planning team. The purpose of the follow-up interviews was to, first, uncover the opinion of the selected participants regarding the participatory process and, second, to acquire information about attitudinal changes toward the other stakeholder groups (see the main themes of the interviews in Appendix C). They also provided useful information about the role of the participatory process in the resolution of conflict, although it was not a priori planned. The follow-up interviews lasted between $1-2.5 \mathrm{~h}$, with an average of $1.5 \mathrm{~h}$ and were documented by written notes.

The interviews and focus groups adhered with the basic ethical principles of social research securing voluntary participation, confidentiality and anonymity, and causing no harm to participants (Patton, 2002; SRA, 2003).

\subsubsection{Methods for analysis}

Currently, most studies on conservation conflicts follow a case study approach without a theoretical framework (White et al., 2009). Nevertheless, theoretical considerations can be used from different fields, e.g. sociology (Dahrendorf, 1958), social-psychology (Deutsch, 1949, 1973) or political ecology (Martinez-Alier, 2002). Analytical frameworks are also diverse (e.g. Vatn, 2005; White et al., 2009; Dickman, 2010; Young et al., 2010), but still can be further developed.

The conceptual basis for analysing participatory processes is not uniform either. Analytical frameworks vary, focusing on the outcomes, the process or both (Kiss, 2014), but they usually do not particularly address conflict resolution.

Our aim was to analyse a participatory process from the point of view of conflict resolution, therefore we decided to search for an analytical framework in the conflict management literature. As Moore, (2003) analytical framework was developed to analyse complex social conflict situations, and to assist the conflict resolution process, it seemed well suited both to reveal the multifaceted nature of conflicts and to analyse the success of the participatory process in resolving the conflict. It was also sufficiently comprehensive, integrating many elements from the framework used by others (e.g. Vatn, 2005). Moore identified five main types of conflict connected to different causes: (1) structural conflicts, (2) interest conflicts, (3) data conflicts, (4) relationship conflicts and 5) value conflicts. Structural conflicts are caused by the unequal distribution of resources or unequal power, but time or legal constraints, geographical, physical or environmental factors hindering cooperation can also be important. Interest conflicts are related to the perceived or actual competition over substantive interests. Data conflicts can be caused by a lack of information, misinformation, contesting views on the relevance of data, differing interpretations of data, or by following different assessment procedures. Value conflicts are
Two consultation forums were organised for local stakeholder based on different ways of life, ideology, religion, or on different criteria for evaluating ideas or behaviour. Relational conflicts might involve strong emotions, misperceptions or stereotypes, and are exacerbated by poor or faulty communication.

Notes made during the semi-structured interviews (prior to the lysed in order to identify the main causes of the conflict, while transcriptions of the forums and notes of the follow-up interviews were used to investigate the progress made during the participatory process in resolving those causes. A qualitative content-analysis method (Stemler, 2001) was applied to assess the conflict and the process, as well using Nvivo software (Bazeley and Jackson, 2013; http2) by applying a priori codes based on Moore's typology. Separated codes were used for analysing the conflict, and for analysing the success of the process in resolving the conflict. Two members of the research team conducted the content analysis separately, and the results were compared and discussed in order to have a crosschecked final result. Regarding structural conflicts, results from the interviews and forums were also checked using the background documents and relevant regulation.

\section{Results}

\subsection{Conflict analysis}

The following section synthesises the various causes of the conflict (conflict types) using Moore (2003) categorisation.

\subsubsection{Structural conflicts}

One of the most significant structural conflicts in the Jászság SPA was related to the system of property and user rights. At the time of the research most of the land in the area was private agricultural land. Although the national park directorate undertook conservation supervision of the Natura 2000 site, and the hunting associations had specific user rights related to game species, neither party was able to directly influence the habitats of small game species. The success in conserving small game species, and the Imperial Eagle, depended primarily on farmers' activities. game management regulations hindered any effective cooperation of game managers and conservationists in the conservation of both the Imperial Eagle and small game species. The nature conservation regulation focused on the protected species of Hungarian and European importance, neglecting non-protected game species; while regulation on game management considered only game species, failing to consider birds of prey.

In the Jászság SPA, arable land was the predominant land use pattern. Farmers cultivating arable land were not eligible for Natura 2000 compensatory payments co-financed by the EU. Therefore, they were not financially encouraged to support conservation goals, given that their costs were not compensated. Furthermore, the EU's agricultural subsidies also had the side effect of causing habitats to deteriorate, because the requirements of direct agricultural payments had not been harmonised with the goals of nature conservation and local game management. Direct agricultural payments could only be received for cultivated land; uncultivated grassy patches and field margins were excluded. This arrangement forced farmers to maximise the areas they cultivated, accelerating the loss of important small game habitats.

Related to game management, another structural problem was mentioned by some hunters, i.e. the current means of predator control permitted by regulation were inefficient and costly.

\subsubsection{Interest conflicts}

The main interest of local farmers was to maximise revenues from farming activities and agricultural payments. Therefore, they consultation forums) and transcriptions of the forums were ana-

The difference in focus between conservation regulation and 
Table 1

Q9 Main characteristics of the methods used in the participatory process.

\begin{tabular}{|c|c|c|}
\hline Method & Period & Main stakeholder groups involved (number of persons) \\
\hline First round of interviews & September-December 2012 & $\begin{array}{l}20 \text { persons: game managers ( } 6) \text {, farmers ( } 7 \text {, but one was also a } \\
\text { forester), conservationists ( } 2 \text {, one was interviewed twice), } \\
\text { representatives of local governments ( } 2 \text {, agricultural advisors ( } 2) \text {, } \\
\text { representative of the water management directorate ( } 1)\end{array}$ \\
\hline Consultation forums & May and June 2013 & $\begin{array}{l}\text { 1st forum: } 35 \text { persons: game managers ( } 13) \text {, farmers ( } 7 \text {, but one was } \\
\text { also a forester), foresters ( } 1 \text { ), local conservationists ( } 2 \text { ), representatives } \\
\text { of the water management directorate ( } 3 \text { ), representatives of local } \\
\text { governments ( } 2 \text { ), conservationists in the planning team (3), others } \\
\text { excluding the facilitators (e.g. researchers) (4) } \\
\text { 2nd forum: } 20 \text { persons: game managers ( } 4 \text { ) farmers ( } 7 \text { ), agricultural } \\
\text { advisors ( } 2 \text { ), local conservationists ( } 1 \text { ), conservationists in the planning } \\
\text { team (3), others excluding the facilitators (e.g. researchers) ( } 3 \text { ) }\end{array}$ \\
\hline Follow-up interviews & July 2013 & $\begin{array}{l}11 \text { persons: local game managers ( } 5) \text {, farmers ( } 2) \text {, conservationists in } \\
\text { the planning team ( } 4)\end{array}$ \\
\hline
\end{tabular}

farmed intensively, planting profitable crops (wheat, corn, rapeseed and sunflower), and cultivated the largest area possible to receive the maximum amount of payments. At the time of the planning process, they had no interest in maintaining field margins and hedgerows as habitats for small game species. The interviews revealed that they were ambivalent towards birds of prey. While some mentioned the usefulness of raptors in catching harmful small game and rodents, there were concerns about the possible harmful effects that birds of prey would have on poultry (Table 1 ).

The main interest of local game managers was to maintain the population of small game species (especially hare and pheasant), since the income of the hunting organisations was partly based on these species. The interviews and the forums showed that the hare was an especially important game species for hunters. Hare could be hunted or caught and sold alive, but could not be bred intensively in the same way as pheasant. Game managers also had an interest in a cost effective and efficient predator control in the area. One game manager mentioned that he considered the prohibited poisoning methods more cost effective and efficient than the currently allowed methods, such as using traps or cleaning out warrens (Table 2).

The interviews and the forums also showed that the main interest of conservationists in the area, i.e. representatives of the HNPD and members of MME, was to maintain the local Imperial Eagle population and other protected raptors, and to protect the habitats of the prey species.

\subsubsection{Data conflicts}

Our interviews showed that farmers mostly attributed the population decline of small game species to extreme weather conditions, such as droughts and floods. They did not mention in the interviews that their farming activities had negative impacts on small game habitats, and as an ecological consequence, on the population of the Imperial Eagle. The conservation experts and game managers agreed that the loss of habitat due to current agricultural practices is a major factor in the decline of the small game population. However, there was no consensus between the two groups concerning the appropriate population size and the feeding habits of the birds of prey, including the Imperial Eagle, and thus, their impact on the hare population. Game managers contended that birds of prey, especially the Imperial Eagle and common buzzard (Buteo buteo), exerted a relatively large influence on the local hare population, and their current population exceeded the carrying capacity; meanwhile, conservationists stated that the impact was only moderate and the size of the population was adequate (Table 3 ).

\subsubsection{Value conflict}

For conservationists, the Imperial Eagle was a highly valuable, strictly protected bird species and the flagship species of Hungarian bird conservation, with its population successfully increased in recent years. It was considered a keystone species, being the top predator bird in its habitat, and an umbrella species. For game managers and farmers, the Imperial Eagle did not hold such a unique value.

Game managers considered the game species a valuable element of nature, while nature conservationists regarded these small games mostly as the prey species of birds of prey. Game hunting was also important for game managers as a tradition. Some game managers considered themselves "conservationists"; in their interpretation, hunting functions as a stewardship of nature and thus, as a form of conservation.

\subsubsection{Relational conflicts}

Among conservationists, game managers and farmers, there had been little communication, collaboration or involvement in each other's activities before the LIFE+ project. Indeed, there had been a long historical conflict between conservationists, and especially game managers, related to the perceived negative effects of the other group's operation. The interviews showed that there had been a generally low level of trust between the conservationists and game managers, and they had difficulties establishing any kind of long-lasting cooperation. Game managers were also resentful towards farmers, because they thought that farmers were concentrating only on their self-interests and not on the common good.

\subsection{Analysis of the conflict resolution process}

Following Moore (2003) conflict concepts, the progress of the participatory process and its impact on the existing causes of the conflict are described in this section.

\subsubsection{Structural conflicts}

Even if it is very difficult to resolve structural conflicts, in our case, some steps were made toward this direction. During the consultation process, the planning team initiated the preparation of a new High Nature Value Area (HNVA) including the Jászság SPA. HNVAs can be proposed by anyone, but they are designated by the ministry responsible for nature conservation and agriculture, when included in HNVA payment schemes as part of the agrienvironmental payments co-financed by the EU. The planning team of MME prepared a proposal for the HNVA including conservation measures from the management plan, which had been discussed with the main stakeholders. The idea of preparing the HNVA proposal was announced in the first forum, and was supported by 
Table 2

The main causes of the conflicts connected to the most important stakeholder groups.

\begin{tabular}{|c|c|c|c|}
\hline Stakeholders/causes of the conflicts & Farmers & Nature conservationists & Game managers \\
\hline \multirow[t]{2}{*}{ Structural conflicts } & $\begin{array}{l}\text { Agricultural direct payments: } \\
\text { no payments for keeping field } \\
\text { margins }\end{array}$ & Limited control on private land & Limited control on private land \\
\hline & & $\begin{array}{l}\text { Nature conservation regulation } \\
\text { concentrates only on protected } \\
\text { species }\end{array}$ & $\begin{array}{l}\text { Game management regulation } \\
\text { concentrates only on game } \\
\text { species } \\
\text { Permitted means of predator } \\
\text { control are inefficient and } \\
\text { costly }\end{array}$ \\
\hline \multirow[t]{2}{*}{ Interest conflicts } & $\begin{array}{l}\text { Maximise revenue from sales } \\
\text { and subsidies (not maintaining } \\
\text { habitat for small game species) }\end{array}$ & $\begin{array}{l}\text { Conservation of the habitat and } \\
\text { population of Imperial Eagle } \\
\text { and other protected birds of } \\
\text { prey and their prey species }\end{array}$ & $\begin{array}{l}\text { Conservation of small game } \\
\text { population and their habitat }\end{array}$ \\
\hline & & & $\begin{array}{l}\text { Maximise revenue from small } \\
\text { game hunting and selling } \\
\text { caught hare alive }\end{array}$ \\
\hline \multirow[t]{2}{*}{ Data conflicts } & $\begin{array}{l}\text { They name extreme weather } \\
\text { conditions as the main cause of } \\
\text { decline in small game } \\
\text { population }\end{array}$ & $\begin{array}{l}\text { They consider the relatively } \\
\text { low impact of birds of prey on } \\
\text { the hare population }\end{array}$ & $\begin{array}{l}\text { They suppose a large impact of } \\
\text { the birds of prey, including the } \\
\text { Imperial Eagle, on the hare } \\
\text { population }\end{array}$ \\
\hline & & $\begin{array}{l}\text { In their view, the population of } \\
\text { the birds of prey is adequate }\end{array}$ & $\begin{array}{l}\text { They consider the birds of prey } \\
\text { population, including the } \\
\text { Imperial eagle, too large }\end{array}$ \\
\hline \multirow[t]{3}{*}{ Value conflicts } & $\begin{array}{l}\text { The Imperial Eagle has no or } \\
\text { little value }\end{array}$ & $\begin{array}{l}\text { The Imperial Eagle is a flagship, } \\
\text { keystone, umbrella species, } \\
\text { symbol of the success of bird } \\
\text { conservation }\end{array}$ & $\begin{array}{l}\text { Game species are valuable for } \\
\text { hunters }\end{array}$ \\
\hline & & $\begin{array}{l}\text { Game species are considered } \\
\text { only to be prey species of } \\
\text { predator birds }\end{array}$ & $\begin{array}{l}\text { Hunting is valuable as a } \\
\text { tradition }\end{array}$ \\
\hline & & & $\begin{array}{l}\text { Some consider themselves } \\
\text { conservationists }\end{array}$ \\
\hline \multirow[t]{2}{*}{ Relational conflicts } & $\begin{array}{l}\text { Lack of communication and } \\
\text { collaboration with nature } \\
\text { conservationists and game } \\
\text { managers }\end{array}$ & $\begin{array}{l}\text { Lack of communication and } \\
\text { collaboration with farmers and } \\
\text { game managers }\end{array}$ & $\begin{array}{l}\text { Lack of communication and } \\
\text { collaboration with nature } \\
\text { conservationists and farmers }\end{array}$ \\
\hline & & $\begin{array}{l}\text { Low level of trust toward game } \\
\text { managers }\end{array}$ & $\begin{array}{l}\text { Low level of trust toward } \\
\text { conservationists }\end{array}$ \\
\hline
\end{tabular}

Table 3

Summary of the main results of the participatory process in resolving the causes of the conflict.

\begin{tabular}{|c|c|c|}
\hline Causes of the conflict & Steps taken toward the resolution & Further steps needed \\
\hline Structural conflicts & $\begin{array}{l}\text { Preparation of a new HNVA with small game } \\
\text { conservation elements and its inclusion in the } \\
\text { proposal for HNVA payment scheme }\end{array}$ & $\begin{array}{l}\text { Harmonisation of nature conservation and } \\
\text { game management regulation } \\
\text { Introduction of a more efficient predator } \\
\text { control; }\end{array}$ \\
\hline Interests conflicts & $\begin{array}{l}\text { Common interests of nature conservationists } \\
\text { and game managers in the conservation of } \\
\text { small game habitats are recognised } \\
\text { Compromises in the management plan } \\
\text { Preparation of new HNVA and its inclusion in } \\
\text { the payment scheme provides incentives to } \\
\text { farmers for small game habitat conservation }\end{array}$ & $\begin{array}{l}\text { Implementation of the management plan and } \\
\text { new HNVA payment scheme }\end{array}$ \\
\hline Data conflicts & $\begin{array}{l}\text { Information sharing about main goals and } \\
\text { interests of different stakeholder groups }\end{array}$ & $\begin{array}{l}\text { Further discussions between game managers } \\
\text { and nature conservationists about the capacity } \\
\text { and the feeding habits of the birds of prey } \\
\text { Involving and informing more farmers }\end{array}$ \\
\hline Value conflicts & Opportunity to learn about each other's values & $\begin{array}{l}\text { More interaction and cooperation are needed } \\
\text { to learn more about and accept each other's } \\
\text { values }\end{array}$ \\
\hline \multirow[t]{2}{*}{ Relational conflicts } & $\begin{array}{l}\text { Appreciation of involvement by game } \\
\text { managers }\end{array}$ & $\begin{array}{l}\text { More interaction and cooperation are needed } \\
\text { to build trust and stabilise the improving } \\
\text { relationship between game managers and } \\
\text { conservationists }\end{array}$ \\
\hline & Mutual acceptance of each other's work & \\
\hline
\end{tabular}

Please cite this article in press as: Kovács, E., et al., Towards understanding and resolving the conflict related to the Eastern Imperial Eagle (Aquila heliaca) conservation with participatory management planning. Land Use Policy (2016), http://dx.doi.org/10.1016/j.landusepol.2016.02.011 
farmers and game managers. The proposal was submitted to the ministry at the end of 2013 , and was included in the proposal for HNVA payment schemes of the Rural Development Programme 2014-2020. The new Rural Development Programme, including the Jászság HNVA payment scheme was approved by the European Commission in August 2015, the call for application for the HNVA payment schemes appeared in November 2015, and payments will start from 2016. The HNVA preparation marked a major step towards resolving the structural conflicts related to agricultural subsidies, as it contained elements which would reconstruct the previously eradicated field margins of small game habitats. The HNVA scheme also addressed the structural problem arising from the private property rights, providing an incentive for land users to fulfil nature conservation and game management goals.

\subsubsection{Interest conflicts}

The consultation process also helped to move toward the resolution of the main interest conflicts. The most significant result of the participatory process was that the game managers and conservation experts both realised and stated that they have a common interest in protecting and developing the habitats of small game species.

During the forums, nature conservation measures were discussed and better tailored to the needs of farmers in the area. Some restrictions previously proposed by conservationists were eliminated (e.g. prohibition of rolling grasslands), made more flexible (e.g. restrictions on the date of mowing) or substituted with restrictions better suited to the everyday practice of farmers (e.g. green fallow zones instead of pesticide free zones).

The HNVA scheme providing payments to farmers to establish and maintain small game habitats can also assist in solving the main interest conflicts between farmers on one side, and conservationists and game managers on the other.

\subsubsection{Data conflicts}

The consultation process helped settle some of the data conflicts as well. The results of the interviews and conflict analysis were shared with the conservation experts in the planning team before the consultation forums, so they were able to eliminate some of the information conflicts. At the forums, they talked about the goals of the Imperial Eagle conservation project and also about the Natura 2000 network; therefore, participating farmers and game managers became better informed of these issues. The leading nature conservation expert at MME (Birdlife Hungary) emphasised that the current size of the Imperial Eagle population is considered satisfactory in the Jászság SPA from a conservation point of view and no further efforts will be made to increase it. It was important information for the game managers. Nevertheless, regarding the debate on the carrying capacity and the feeding habits of the birds of prey, more discussions are needed between game managers and nature conservationists.

The discussions of conservation measures led to a mutual information exchange among all stakeholder groups. The farmers received an explanation about the importance of the proposed measures from a conservation point of view, while the conservationists (including the experts of the planning team) got feedback about the applicability and acceptability of the measures. During the followup interviews, game managers emphasised that they had gained new information during the forums. The planning experts stated that they needed the knowledge of farmers as 'a reality check' of the proposed measures, because farmers had practical experience in the area.

\subsubsection{Value conflict}

The consultation process gave an opportunity for stakeholders to learn more about each other's values. However, the follow-up interviews showed that value orientations are quite stable and mutual acceptance of each other's values will probably take time. Some examples (e.g. the involvement of game managers in nature conservation activities such as ringing) showed that cooperation can foster this process.

\subsubsection{Relational conflict}

During the consultation process, the main stakeholders had an opportunity to form an opinion about the nature conservation goals and requirements, which also assisted in resolving relational conflicts. Game managers, in particular, appreciated that they had been invited to participate and were treated as partners.

The forums and the follow-up interviews also showed that game managers and conservationists were starting to appreciate each other's work.

Many participants emphasised the importance and need for further cooperation, especially between game managers and nature conservationists, but also between the latter two groups and farmers.

\section{Discussion}

\subsection{Reflecting on the analytical framework}

In our study Moore's analytical framework with the five categories of conflicts proved to be useful in analysing nature conservation conflicts and revealing even a complex conflict situation. However, these various types of conflicts are also interconnected with each other, adding to the complexity of the situation, which is not captured by Moore's framework. On one hand, conflicts inherent in structural frames can have an impact on the interest conflicts (in our case, the requirements of the agricultural subsidies determined the main interests of the farmers). On the other hand, value conflicts can affect the relations between stakeholders (in our case, the opposing value systems of game managers and nature conservationists made it difficult for these groups to establish a good relationship). These examples show that further research and more case studies are needed in order to uncover the interactions between the different causes of the conflicts, and to integrate them into this framework.

\subsection{External factors contributing to the success of conflict resolution}

A new seven-year period started in 2014 for agricultural subsidies and payments co-financed by the EU. The timing of the consultation process was convenient, as it was possible to include the new HNVA with the proposed conservation measures in the planning of the new payment schemes for HNVAs. Morelli (2013) and Morelli et al. (2014) show that HNVAs are important for many bird species partly because they provide habitats through hedgerows, trees and field margins thus increasing the heterogeneity of the landscape. However, in our case still much effort needs to be taken by the HNPD to encourage farmers to apply for funding, because the HNVA payments scheme is new for farmers in this area and there is a short period of time for the application. Without this payment scheme the success of encouraging farmers to take voluntary actions to establish habitat for small game species probably would have been limited.

The 'greening' of the direct agricultural payments was introduced in the new budget period (2014-2020) of the EU. If this is successfully implemented, it will also increase field margins and green areas in arable land, providing habitat for small game species, even in those areas where land users do not participate in the HNVA payment scheme (Hart, 2015). In the areas of HNVAs, the measures are harmonised with the greening measures. 
The LIFE+ project had other actions with a positive effect on conflict resolution. While the Hunters' National Chamber was a project partner involved in many actions, co-operation started between the two stakeholder groups involving local hunting organisations (e.g. traps have been distributed to them). Research and monitoring of small game species and predators were conducted in the area, the results of which were shared on the project website. A new visitor and research centre has been established in the area as well, showing the main natural values of the Jászság SPA and giving insight into the conservation of the Imperial Eagle and other raptor species.

\subsection{Some strengths of the participatory process}

Literature on conservation related participation emphasises that the success of participatory processes highly depends on how they are implemented (Reed, 2008; Booth and Halseth, 2011). In our case interviews and consultation forums were chosen to involve the main stakeholder groups. Interviews before the forums helped to build trust with the various stakeholders, attract their attention and strengthen their engagement. All three are important factors for a constructive participatory process. During the interviews interviewees were able to share their knowledge, ideas and concerns about the conservation of Imperial Eagle and other birds of prey in the Jászság SPA with someone actually willing to listen, generating political recognition (Honneth, 1995). Interviews also provided the management team with information about the main conflicts and showed the potential for future cooperation as well. Consultation forums played an especially important role in knowledge sharing, mutual learning about the values and interests of other stakeholder groups and in generating new ideas (e.g. changing restrictions in a way that can be acceptable for both conservationists and farmers). Follow-up interviews provided the opportunity for interviewees to give their feedback on the process.

Evaluating the entire process it is the impression of the authors of this paper that the interdisciplinary composition and approach of the management team also contributed to the achievements. Conservation experts are usually trained as natural scientists with intimate knowledge about natural habitats and protected species but with less experience in communication, participatory processes or conflict resolution (Madden and McQuinn, 2014). This one-sided professionalism has actually been pointed out to be a significant pitfall in nature conservation conflicts (O'Rourke, 2014). Our study shows that involvement of experts with social science training and experience in participatory methods can be fruitful in conservation related participatory processes, especially in conflict situations.

Many scholars underline that the balance of power is a crucial factor in any participatory processes (Reed, 2008; Booth and Halseth, 2011). The participatory planning process in our case was initiated by a nature conservation civil organisation and not by an administrative nature conservation body. In our view it provided a good opportunity for a balanced power relationship and avoided domination of one party over others.

\section{${ }_{641}$ 4.4. Limits of the participatory process}

Although we consider the participatory process successful in taking steps toward resolving the main conservation conflict in the Jászság SPA, the process was not without its shortcomings. The planning process lasted approximately one year. While this was long enough to mobilise some stakeholders to participate in the preparation of the management plan and foster cooperation, further efforts are needed to implement the proposed measures and to establish a successful, long-lasting relationship. Literature on participation also emphasises the time consuming character of participatory processes (Reed, 2008; Booth and Halseth, 2011).
Studies discussing stakeholder participation underline the importance of involving all stakeholder groups at a satisfactory level to reach a good result and increase the legitimacy of the process (Reed, 2008). In this case farmers could not be mobilised at a satisfactory level during the planning process (mostly due to insufficient data) therefore, further efforts are needed to involve them in the next steps, especially related to the new HNVA scheme.

Another shortcoming was that some structural causes of the conflict raised by the stakeholders could not be remedied (e.g. conservation and game management regulation have not been harmonised; efficient predator control within the current regulatory framework could not be developed). However, changing these structures is usually a complex task; it is time consuming and requires the sustained, coordinated efforts of interested parties.

The same could be said for the transformation of attitudes and values which caused a hindrance in managing the value conflicts related to Imperial Eagle conservation within a short period of time. This emphasises the importance of long term and consistent planning and management horizons. The goal could be to reach a mutual acceptance of differing values among the stakeholders. Cooperation can foster this process, as the different stakeholder groups can have insight into the activities of other groups, understand the main goals and motivations behind their actions and through this the views and value orientation of the other stakeholder groups as well.

\subsection{The ambiguities of the 'stakeholder' concept}

As mentioned in the introduction, scholars from a deliberative democratic point of view have criticised stakeholder participation as the means by which societal goals and plans are realised. The main argument is that stakeholder participation strengthens the interest groups in society already holding the power, by addressing the participants as stakeholders instead of citizens, while excluding the broader public and eroding the collective responsibility (Hansen et al., in press). However, it is hard to imagine that a conservation conflict, such as the one described in this paper, involving privately owned farmland, would be possible to resolve without systematically targeting the strategic interests of the stakeholders of the conflict. Nevertheless, the outcome of the presented stakeholder participation process to some extent did manage to transcend the strategic dimension of the conflict by creating a space to develop a shared responsibility by identifying the resources and values as 'commons'. Hunters and nature conservationists started to consider both the eagle and the hare population as important common assets. It can be seen as a step towards a more equal, mutual respectful and collective responsibility, the treatment of the participants as citizens, and not necessarily as a reinforcement of those already holding the power.

\subsection{Relevance of the study in the CEE context}

Our study reinforces the results of other studies that emphasise the importance of participatory processes in the resolution of conservation conflicts (Messmer, 2000; Reed, 2008; Treves et al., 2009; Jones-Walters and Çil, 2011). In our view gaining experience in participatory processes in nature conservation is especially important in CEE countries, where top-down processes have dominated nature conservation decision-making (Niedziałkowski et al., 2014). Our case is congruent with other studies, which show that participation related to nature conservation is also gaining importance in this region (e.g. Rodela and Udovč, 2008; Švajda, 2008; Cent et al., 2014). Participation in CEE countries is usually at a medium level according to the categorisation of Arnstein (1969), not reaching the real sharing of power. Nevertheless, if the participatory process gives the opportunity to stakeholders to share their opinion 
and views about the topic under discussion and if these views are taken into account in the final decision, then it can be considered a good step toward enhanced participation. The participatory process described in this paper is a good example for this potential.

\section{Conclusion}

The case study presented in this paper focused on a stakeholder oriented participatory management planning process of a Natura 2000 site and a related conservation conflict in Jászság SPA, Hungary. It demonstrated that such a participatory process can reveal conflicts among different stakeholder groups concerning the land use at the given site, so understanding and managing the conflicts is important for the success of the whole process. Identifying underlying causes of the conflict, such as problems related to financial and political structural conflicts, conflicting interest, lack of information, deviating values and relationship tensions, and creating a communicative space based on mutual respect and recognition via facilitated dialogue contributed to the successful management of the Natura 2000 site. The acceptability of proposed conservation measures and the reduction of the conflict level were beneficial to most stakeholders as well as to the nature conservation programs. The establishment of an administrative and financial incentive such as the HNVA scheme proved to be an especially important factor for conflict management and also contributed to a more successful realisation of nature conservation objectives in an area dominated by private land owners.

\section{Acknowledgements}

The research was carried out within the HELICON LIFE+ project (Conservation of Imperial Eagles by managing human-eagle conflicts in Hungary-LIFE10NAT/HU/019) with the financial support of the European Commission. Designing and carrying out the participatory research was hosted and supported by the ESSRG Ltd. Authors at Szent István University were supported by the Research Centre of Excellence (9878/2015/FEKUT). We would like to thank the members of the Environmental Social Science Research Group for their valuable support. We also thank the conservation experts of MME Birdlife Hungary (Márton Horváth, Attila Králl, Péter Tóth and Dénes Nagy) responsible for the preparation of the management plan of the Jászság SPA, for their cooperation in the participatory process. We would like to thank László Szemethy of Szent István University for the consultation on game management issues. We are grateful for the interviewees and the participants of the stakeholder forums for sharing their thoughts and opinions with us, and for their active participation in the process. We also thank Viktória Tóth from Szent István University and Gyula Nagy from Corvinus University of Budapest for their assistance in conducting the interviews. We highly appreciate the work of Dániel Molnár of Szent István University, who prepared the map for this paper. We are grateful for Erica von Essen from the Swedish University of Agricultural Sciences and Andrew Reid for the English proofreading. And we also thank the anonymous reviewers for their valuable comments and suggestions.

\section{Appendix A. Summary of the main themes covered in the first round of interviews before the consultation forums}

A separate interview line was prepared for each main stakeholder group, tailored to the characteristics of each group. Here, only a summary of the main themes covered in the interviews is given.
1. Short introduction by the interviewer about the purpose of the interview.

2. Introduction work and professional background of the interviewee; main activities of the organisation he/she represents.

3. Local circumstances: local livelihood, employment opportunities; state of local agriculture; local cooperation between farmers.

4. Main local stakeholders and their relations: perceptions about other stakeholder groups and their impacts on each other's activities; main relationships between the stakeholder groups.

5. Agricultural subsidies: received agricultural payments, including agri-environmental, forest-environmental schemes and Natura 2000 compensatory payments; perception about these payments; suggestions for improvement.

6. Natural values, protection of birds of prey (especially the Imperial Eagle) and small game species: practical knowledge; experience and perception about natural values, including birds of prey and small game species; perception of the population size of these species; impact of these species on economic activities; impact of the economic activities on these species; threats to these species; problems and conflicts related to these species; perception about the conservation of these species; suggestions for the effective conservation of these species.

7. Changes in the landscape: perceived changes in the landscape in the last few decades and the reasons behind them; changes in land use, perceived changes in the population size of birds of prey (especially the Imperial Eagle) and small game species.

8. Closing the interview: acknowledging the interviewees time; asking about the willingness of the interviewee to further cooperate and participate in the consultation process and forums; suggestions for further contacts.

\section{Appendix B. Agendas of the stakeholder forums}

1st stakeholder forum

Introduction $(1 \mathrm{~h})$

1 Forum opening (member of the facilitator team).

2 General information about the Natura 2000 network and the management plan (member of the planning team, Birdlife Hungary).

3 Introducing the planning process of the Jászság Special Protection Area and the Helicon LIFE project (member of the planning team, Birdlife Hungary).

4 Presenting the natural values of the Jászság SPA (member of the planning team, Birdlife Hungary).

5 Presenting the recommended conservation measures in the SPA (member of the planning team, Birdlife Hungary).

\section{Discussion (1 h)}

6 Moderated discussion: questions, remarks, opinions (moderated by a member of the facilitator team).

Closing and lunch $(1 \mathrm{~h})$

7 Closing of the forum (member of the facilitator team). 8 Lunch.

2nd stakeholder forum Introduction $(0.5 \mathrm{~h})$

1 Forum opening (member of the facilitator team).

\section{7 \\ 77

Please cite this article in press as: Kovács, E., et al., Towards understanding and resolving the conflict related to the Eastern Imperial Eagle (Aquila heliaca) conservation with participatory management planning. Land Use Policy (2016), http://dx.doi.org/10.1016/j.landusepol.2016.02.011 
2 Presenting the recommended conservation measures in the SPA and the results of the consultation of the first forum (members of the planning team, Birdlife Hungary).

\section{Discussion, part $1(1.5 \mathrm{~h})$}

3 Moderated discussion: questions, remarks, opinions (moderated by a member of the facilitator team).

Lunch break ( $1 \mathrm{~h})$

Discussion, part $2(2.5 \mathrm{~h})$

4 Moderated discussion: questions, remarks, opinions (moderated by a member of the facilitator team).

\section{Appendix C. Summary of the main themes covered in follow-up interviews after the consultation forums}

A separate interview line was prepared for each main stakeholder group, tailored to the characteristics of each group. Here, only a summary is given of the main themes covered in the interviews.

1 Short introduction by the interviewer about the purpose of the interview.

2 Motivation of the stakeholders: motivations for being involved in the participatory process.

3 Changing knowledge and opinions related to nature conservation: knowledge gained about the Natura 2000 network and the Imperial Eagle; changes in opinion about nature conservation and the conservationists work; reasons behind it.

4 Changes in opinion about the other stakeholder groups: change in the stakeholders views in relation to the roles of the other stakeholder groups in reaching the goals of the Natura 2000 network and the conservation of the Imperial Eagle; changes in the relationships with other stakeholder groups due to the consultation process, or due to external factors.

5 Opinions about the participatory process: views about the consultation process; perceived effectiveness of the process and its results; expectations about the forums; satisfaction with the process and the results; suggestions for improving the process and the forums.

6 Opinions about the management plan and its implementation: expectations about the management plan; satisfaction with the management plan; expectations and personal views about the implementation of the management plan; opinions about the proposed HNVA scheme.

7 Closing the interview: acknowledging the interviewee's time

\section{References}

Anthony, B., Moldovan, D., 2008. Poised for engagement? Local communities and Macin Mountains National Park, Romania. Int. J. Biodivers. Sci. Manag. 4, 230-241.

Anthony, B.P., Szabo, A., 2011. Protected areas: conservation cornerstones or paradoxes? Insights from human-wildlife conflicts in Africa and Southeastern Europe. In: López-Pujol, J. (Ed.), The Importance of Biological Interactions in the Study of Biodiversity. InTech Publishers, Rijeka, pp. 255-282.

Arnstein, A., 1969. A ladder of citizenship participation. J. Am. Inst. Plan. 26 216-233.

Arthur, R., Kelkar, N., Alcoverro, T., Madhusudan, M.D., 2013. Complex ecological pathways underlie perceptions of conflict between green turtles and fishers in the Lakshadweep Islands. Biol. Conserv. 167, 25-34.

Bagnoli, P., Timo, G., Kovács, E., 2008. People and Biodiversity Policies, Impacts, Issues and Strategies for Policy Action. OECD Publications, Paris.

Bazeley, P., Jackson, K., 2013. Qualitative Data Analysis with Nvivo, second edition. Sage, London, $308 \mathrm{pp}$.

BirdLife International, 2013. Aquila heliaca. The IUCN Red List of Threatened Species 2013. e.T22696048A40763222. <http://dx.doi.org/10.2305/IUCN.UK. 20132.RLTS.T22696048A40763222.en> (accessed September 2015).
Blicharska, M., Angelstam, P., 2010. Conservation at risk: conflict analysis in the Białowieża Forest, a European biodiversity hotspot. Int. J. Biodivers. Sci. Ecosyst. Serv. Manag. 6 (1-2), 68-74.

Booth, E., Halseth, G., 2011. Why the public thinks natural resources public participation processes fail: a case study of British Columbia communities. Land Use Policy 28, 898-906.

Bro, E., Arroyo, B., Migot, P., 2006. Conflict between grey partridge Perdix perdix hunting and hen harrier Circus cyaneus protection in France: a review. Wildl. Biol. 12, 233-247.

Bulkeley, H., Mol, A.P.J., 2003. Participation and environmental governance: consensus, ambivalence and debate. Environ. Values 12 (2), 143-154.

Cent, J., Grodzińska-Jurczak, M., Pietrzyk-Kaszyńska, A., 2014. Emerging multilevel environmental governance-a case of public participation in Poland. J. Nat. Conserv. 22, 93-102.

Dahrendorf, R., 1958. Toward a theory of social conflict. J. Confl. Resolut. 2 (2), 170-183.

Deutsch, M., 1949. A theory of cooperation and competition. Hum. Relat. 2, 129-152.

Deutsch, M., 1973. The Resolution of Conflict: Constructive and Destructive Processes. Yale University Press, New Haven.

Dickman, A.J., 2010. Complexities of conflict: the importance of considering social factors for effectively resolving human-wildlife conflict. Anim. Conserv. 13, $458-466$.

Díez, M.A., Etxano, I., Garmendia, E., 2015. Evaluating participatory processes in conservation policy and governance: lessons from a Natura 2000 pilot case study. Environ. Policy Gov. 25, 125-138.

Freeman, R., 1984. Strategic Management: A Stakeholder Approach. Pitman, Boston.

Grujčič, I., Milijić, V., Nonič, D., 2008. Conflict management in protected areas: the Lazar Canyon natural monument Eastern Serbia. Int. J. Biodivers. Sci. Manag. 4, 219-229.

Hansen, H.P., von Essen, E., Sriskandarajah, N. Citizens, values and experts: stakeholders: the inveigling factor of participatory democracy. In: Hansen, H.P., Nielsen, B.S., Sriskandarajah, N., Gunnarsson, E., (Eds.), Commons, Sustainability, Democratization Action Research and the Basic Renewal of Society. Routledge, New York, pp. 113-138.

Hart, K., 2015. Green Direct Payments: Implementation Choices of Nine Member States and Their Environmental Implications. IEEP, London.

Honneth, A., 1995. The Struggle for Recognition-The Moral Grammar of Social Conflict. Polity Press, Cambridge.

Horváth, M., Szitta, T., Firmánszky, G., Solti, B., Kovács, A., Moskát, C., 2010. Spatial variation in prey species composition and its possible effects on reproductive success in an expanding Eastern Imperial Eagle (Aquila heliaca) population. Acta Zoologica Academiae Scientiarum Hungaricae 56 (2), 187-200.

Horváth, M., Demeter, I., Fatér, I., Firmánszky, G., Kleszó, A., Kovács, A., Szitta, T., Tóth, I., Zalai, T., Bagyura, J., 2011. Population dynamics of the Eastern Imperial Eagle (Aquila heliaca) in Hungary between 2001 and 2009. Acta Zoologica Bulgaria (Suppl. 3), 61-70.

Horváth, M., Bagyura, J., Fatér, I., Firmánszky, G., Juhász, T., Klébert, A., Pongrácz, Á. Prommer, M. Szelényi, B., Váczi, M., 2012. A Parlagisas-védelmi és Mérgezés-megelózési Munkacsoportok 2012. évi beszámolója. Heliaca 10, 6-11.

Horváth, M., Szitta, T., Bagyura, J., Fatér, I., Firmánszky, G., Moskát, C., 2014. Simultaneous effect of habitat and age on reproductive success of Imperial Eagles (Aquila heliaca) in Hungary. Ornis Hungarica 22 (1), 57-68.

Jones-Walters, L., Çil, A., 2011. Biodiversity and stakeholder participation. J. Nat. Conserv. 19, 327-329.

Kiss, G., 2014. Why should the public participate in environmental decision-making? Theoretical arguments for public participation. Period. Politech. 22, 13-20.

Kloskowski, J., 2011. Human-wildlife conflicts at pond fisheries in eastern Poland: perceptions and management of wildlife damage. Eur. J. Wildl. Res. 57 295-304.

Kovács, A., Demeter, I., Horváth, M., Fülöp, Gy., Frank, T., Szilvácsku, Zs., 2005. Imperial Eagle Management Guidelines. MME/BirdLife Hungary, Budapest.

Kovács, A., Demeter, I., Fatér, I., Bagyura, J., Nagy, K., Szitta, T., Firmánszky, G. Horváth, M., 2008. Current efforts to monitor and conserve the Eastern Imperial Eagle Aquila heliaca in Hungary. Ambio 37 (6), 457-459.

Kovács, E., Kelemen, E., Kalóczkai, Á., Margóczi, K., Pataki, Gy., Gébert, J., Málovics, Gy., Bálint, B., Roboz, Á., Krasznai Kovács, E., Mihók, M., 2015. Understanding the links between ecosystem service trade-offs and conflicts in protected areas. Ecosyst. Serv. 12, 117-127.

KSH, 2012. Földhasználat és állatállomány Magyarországon, 2010 (településsoros adatok), Magyarország mezőgazdasága (ÁMÖ), 2010. Központi Statisztikai Hivatal, Budapest.

Lawrence, A., 2008. Experiences with participatory conservation in post-socialist Europe. Int. J. Biodivers. Sci. Manag. 4, 179-186.

Madden, F., 2004. Creating coexistence between humans and wildlife: global perspectives on local efforts to address human-wildlife conflict. Hum. Dimens. Wildl. 9, 247-257.

Madden, F., McQuinn, B., 2014. Conservation's blind spot: the case for conflict transformation in wildlife conservation. Biol. Conserv. 178, 97-106.

Malatinszky, Á., Ádám, Sz., Saláta-Falusi, E., Saláta, D., Penksza, K., 2013. Planning management adapted to climate change effects in terrestrial wetlands and grasslands. Int. J. Glob. Warm. 5 (3), 311-325.

\section{6}

$$
\begin{aligned}
& 887 \\
& 888 \\
& 889
\end{aligned}
$$

$$
88
$$

$$
\begin{aligned}
& 890 \\
& 891 \\
& 892
\end{aligned}
$$$$
\begin{aligned}
& 893 \\
& 894
\end{aligned}
$$

$$
\begin{aligned}
& 898 \\
& 899 \\
& 900
\end{aligned}
$$

\section{901}

\section{904}$$
\begin{aligned}
& 90.5 \\
& 906
\end{aligned}
$$

$$
\begin{aligned}
& 906 \\
& 907 \\
& 908 \\
& 909
\end{aligned}
$$$$
\begin{array}{r}
908 \\
909 \\
910
\end{array}
$$$$
\begin{aligned}
& 911 \\
& 912
\end{aligned}
$$$$
\begin{aligned}
& 912 \\
& 913
\end{aligned}
$$$$
\begin{aligned}
& 921 \\
& 922 \\
& 923
\end{aligned}
$$

$$
\begin{aligned}
& 924 \\
& 925 \\
& 926
\end{aligned}
$$


Marshall, K., White, R., Fischer, A., 2007. Conflicts between humans over wildlife management: on the diversity of stakeholder attitudes and implications for conflict management. Biodivers. Conserv. 16 (11), 3129-3146.

Martinez-Alier, J., 2002. The Environmentalism of the Poor: A Study of Ecological Conflicts and Valuation. Edward Elgar, Cheltenham.

Messmer, T.A., 2000. The emergence of human wildlife conflict management: turning challenges into opportunities. Int. Biodeterior. Biodegrad. 45, 97-102.

MME (Birdlife Hungary), 2010. Conservation of imperial eagles by managing human-eagle conflicts in Hungary. LIFE+ Nature \& Biodiversity Technical Application Forms Part A-administrative information.

MME (Birdlife Hungary), 2013. A Jászság különleges madárvédelmi terület (HUHN10005) Natura 2000 fenntartási terve, szerk. Králl Attila, Budapest.

Morelli, F., 2013. Quantifying effects of spatial heterogeneity of farmlands on bird species richness by means of similarity index pairwise. Int. J. Biodivers. 2013, Article ID 914837, 9 pp. http://dx.doi.org/10.1155/2013/914837 (accessed November 2015).

Morelli, F., Jerzak, L., Tryjanowski, P., 2014. Birds as useful indicators of high nature value (HNV) farmland in Central Italy. Ecol. Indic. 38, 236-242.

Moore, C.W., 2003. The Mediation Process: Practical Strategies for Resolving Conflict, 3rd edition. Jossez-Bass, A. Wiley Imprint, San Francisco.

Niedziałkowski, K., Blicharska, M., Mikusinski, G., Jedrzejewska, B., 2014. Why is it difficult to enlarge a protected area? Ecosystem services perspective on the conflict around the extension of the Białowieza National Park in Poland. Land Use Policy 38, 314-329.

O'Rourke, E., 2014. The reintroduction of the white-tailed sea eagle to Ireland: People and wildlife. Land Use Policy 38, 129-137.

Patton, M.Q., 2002. Qualitative Research and Evaluation Methods. Sage, London. Pellizzoni, L., 2003. Uncertainty and Participatory Democracy. Environ. Values 12 (2), 195-224.

Rauschmayer, F., van den Hove, S., Koetz, T., 2009. Participation in EU biodiversity governance: how far beyond rhetoric? Environ. Plan. C: Gov. Policy 27, 42-58.

Redpath, S., Arroyo, B., Leckie, F., Bacon, P., Bayfield, N., Gutierrez, R., Thirgood, S., 2004. Using decision modelling to resolve human-wildlife conflicts: a case study with raptors and grouse. Conserv. Biol. 18, 350-359.

Redpath, S.M., Young, J., Evely, A., Adams, W.M., Sutherland, W.J., Whitehouse, A., Amar, A., Lambert, R.A., Linnell, J.D.C., Watt, A., Gutiérrez, R.J., 2013. Understanding and managing conservation conflicts. Trends Ecol. Evol. 28 (2), $100-109$.

Reed, M.S., 2008. Stakeholder participation for environmental management: a literature review. Biol. Conserv. 141, 2417-2431.

Reed, M.R., Graves, A., Dandy, N., Posthumus, H., Hubacek, K., Prell Ch Quinn, C.H., Stringer, L.C., Morris, J., 2009. Who's in and why? A typology of stakeholder analysis methods for natural resource management. J. Environ. Manag. 90, 1933-1949.

Rodela, R., Udovč, A., 2008. Participation in nature protection: Does it benefit the local community? A Triglav National park case study. Int. J. Biodivers. Sci. Manag. 4, 209-218.

SRA (Social Research Association), 2003. Ethical guidelines UHL. <http://the-sra. org.uk/wp-content/uploads/ethics03.pdf> (assessed January 2016).

Stemler, S. 2001. An overview of content analysis. Practical Assessment, Research \& Evaluation 7(17). UHL. <http://PAREonline.net/getvn.asp?v=7\&n=17> (accessed October, 2015).
Švajda, J., 2008. Participatory conservation in a post-communist context: the Tatra National Park and Biosphere Reserve, Slovakia. Int. J. Biodivers. Sci. Manag. 4, 200-208.

TEEB, 2010. The Economics of Ecosystems and Biodiversity: Ecological and Economic Foundations. In: Kumar, Pushpam (Ed.). Earthscan, London and Washington.

Thirgood, S., Woodroffe, R., Rabinowitz, A., 2005. The impact of human-wildlife conflict on human lives and livelihoods. In: Woodroffe, R., Thirgood, S., Rabinowitz, A. (Eds.), People and Wildlife, Conflict or Coexistence? Cambridge University Press, Cambridge, pp. 1-12 (Chapter 2).

Thirgood, S., Redpath, S., 2008. Hen harriers and red grouse: science, politics and human-wildlife conflict. J. Appl. Ecol. 45, 1550-1554.

Treves, A., Wallace, R.B., Naugthon-Treves, L., Morales, A., 2006. Co-managing human-wildlife conflicts: a review. Hum. Dimens. Wildl. 11, 383-396.

Treves, A., Wallace, R.B., White, S., 2009. Participatory planning of interventions to mitigate human-wildlife conflicts. Conserv. Biol. 23 (6), 1577-1587.

Václavíková, M., Václavík, T., Kostkan, V., 2011. Otters vs. fishermen: stakeholders' perceptions of otter predation and damage compensation in the Czech Republic. J. Nat. Conserv. 19, 95-102.

Vatn, A., 2005. Institutions and the Environment. Edward Elgar, Cheltenham.

White, R.M., Fischer, A., Marshall, K., Travis, J.M.J., Webb, T.J., di Falco, S., Redpath, S.M., van der Wal, R., 2009. Developing an integrated conceptual framework to understand biodiversity conflicts. Land Use Policy 26, 242-253.

Young, J., Richards, C., Fischer, A., Halada, L., Kull, T., Kuzniar, A., Tartes, U., Uzunov, Y., Watt, A., 2007. Conflicts between Biodiversity Conservation and Human Activities in the Central and Eastern European Countries. Ambio 36 (7), 545-550.

Young, J.C., Marzano, M., White, R.M., McCracken, D.I., Redpath, S.M., Carss, D.N., Quine, C.P., Watt, D., 2010. The emergence of biodiversity conflicts from biodiversity impacts: characteristics and management strategies. Biodiversity Conservation 19, 3973-3990.

Young, J.C., Jordan, A., Searle, K.R., Butler, A., Chapman, D.S., Simmons, P., Watt, A.D., 2013. Does stakeholder involvement really benefit biodiversity conservation? Biological Conservation 158, 359-370.

Zimmermann, A., Walpole, M.J., Leader-Williams, N., 2005. Cattle ranchers' attitudes to conflicts with jaguar Panthera onca in the Pantanal of Brazil. Oryx 39 (4), 406-412.

\section{Web references}

http://ec.europa.eu/environment/life/about/index.

htm\#history, accessed November 2015. www.qsrinternational.com, accessed November 2015. 